\title{
Do self-employment rates converge? \\ Evidence from European OECD countries
}

\author{
George Saridakis \\ The University of Kent, Business School, UK \\ G.Saridakis@kent.ac.uk \\ Miguel A. Mendoza Gonzalez \\ Department of Economics, UNAM, Mexico \\ mendozag@unam.mx
}

Rebeca I. Muñoz Torres

Department of Economics and Quantitative Methods, Westminster University

R.Munoztorres@westminster.ac.uk

Chris Hand

Kingston Business School, Kingston University, UK

C.Hand@kingston.ac.uk

\begin{abstract}
This paper uses panel data methods for stationary and non-stationary data to examine whether self-employment rates converge for 21 OECD European countries from 19902011 (the period covered by the COMPENDIA database). This paper shows that there is a process of conditional convergence of self-employment rates particularly within Southern, Northern and Western Europe. These regional groups were characterised by a decreasing trend in their average self-employment rates. While in Central Europe, we find more mixed results across the tests used and observe a rising trend in the average self-employment rates. Finally, we find some weak evidence of convergence among all European countries.
\end{abstract}




\section{Introduction}

Self-employment is a major source of work in Europe with nearly $14 \%$ of workers being selfemployed (Hatfield, 2015). Over the years, many European countries have increased their efforts to promote self-employment and incentivise the creation of small firms (Bendick and Egan 1987; Parker et al. 2004; EEOBR, 2010). This is because governments increasingly recognise self-employment as an important engine for stimulating economic growth and innovation - especially during recessions and times of high unemployment, when jobs are scarce (see also interesting discussions in Peric and Vitezic, 2016; Wright and Stigliani, 2012; Acs, 2006; Minniti and Lévesque, 2010; van Stel et al., 2005; Storey, 1994 among others). Promoting self-employment as a driver of sustainable economic growth remains a feature of European Union (EU) policy, in particular as part of the Europe 2020 Strategy with self-employment (and entrepreneurship more generally) being supported via the European Process Microfinance Facility, the Employment and Social Innovation Programme and the European Social Fund (European Commission, no date).

Despite this general view over this form of entrepreneurship, European selfemployment rates differ substantially across countries and within regions. Most of the existing empirical work focuses on explaining these disparities and provide useful insights into the determinants of self-employment (e.g. Blanchflower, 2000, 2004; Parker and Robson, 2004; Torrini, 2005). For example, Torrini (2005) finds evidence that selfemployment rates across OECD countries are related to public sector employment levels, unemployment benefit replacement rate and taxation arrangements. Employment protection legislation also has an effect; Taylor (2011) finds a positive association between strictness of protection legislation and entry into self-employment. Greater employment protection legislation produces a less dynamic labour market with less job creation. These influences on self-employment could all be influenced by EU policy as well as national policy.

However, little is still known about how the countries perform relative to each other, especially when considering groups of countries with integrated economies such as members of single markets, customs unions or free trade areas. One exception to this is Schindele's (2010) study of self-employment in Germany, which finds that in the years immediately after re-unification, East German regions on average quickly caught up with West German regions. However the average disguises the variation across regions. Some regions have caught up to the national average, but others (in particular in the North of the former East Germany) have not caught up and show slowing rates of growth in self-employment. This suggests that 
despite policies to encourage self-employment, the differences between regions will persist for some time within the reunified economy.

Membership of the EU might be expected to result in member states becoming more closely aligned in terms of economic and labour market policy, but also in terms of economic performance as well as other social indicators. The notion of convergence within the EU has received wide research attention with studies of convergence in GDP (e.g. Monfort, Cuestas and Ordóñez, 2013), quality of life (Giannias, Liargovas and Manolas, 1999), welfare indicators (Caminada, Goudswaard and Van Vliet, 2010) and even happiness (Apergis and Georgellis, 2015). These studies have found mixed evidence for convergence; club convergence (i.e. convergence by a subset of states) is more often observed. For example, Monfort et al. (2013) identify two convergence clubs within EU-14 member states and two in a panel of 24 countries. Surprisingly neither reflects a north-south divide. In the EU-14 panel the clubs seem to be defined more by core or peripheral location whilst the 24 country panel seems to display an east - west divide. Convergence in and of itself may not always be advantageous. For example, Caminada et al. (2010) identify convergence to a higher level for replacement rates of unemployment benefits but not for social assistance benefits. Given the convergence of aspects of economic activity such as business cycles across Europe, promoted by open trade and, within the Euro area, a common interest rate and monetary policy, selfemployment rates may be expected to converge too.

Albeit with some idiosyncracies, the evidence supports the notion that business cycles within Europe have converged over time (e.g. Papadimitriou et al., 2016), with convergence accelerated by the creation of the Euro (e.g. Altavilla, 2004). That said, more recently the economies amongst the hardest hit by the global financial crisis (Portugal, Italy, Greece and Spain) have seen their business cycles diverge from the rest of Europe (Cancelo, 2012) and there is some evidence of convergence within regions of Europe rather than across Europe as a whole (e.g. Monfort et al., 2013). Such convergence in business cycles may in turn influence self-employment rates. Although the business cycle is an important influence on self-employment, the nature of the relationship is not clear-cut; people may be pulled into self-employment in times of growth or pushed into it during economic downturns to avoid unemployment (e.g. Svaleryd, 2015). The evidence on national business cycles' effect on self-employment is mixed, with Blanchflower (2000) and Koellinger and Thurik (2012) finding differences in the correlations between business cycles and self-employment rates across countries. Hence, although the two are related, the variability in the correlations implies that other (structural) factors may play a role. The convergence in business cycles in 
Europe and the link between business cycles and self-employment may be expected to lead to a degree of convergence in self-employment rates across Europe over time.

Whilst it is stated policy of the EU to support and increase entrepreneurial selfemployment (particularly as a way of reducing unemployment), convergence in selfemployment rates is not in itself an aim. Convergence in self-employment rates, should it occur, is likely to be a consequence of converging economic growth rates / business cycles and the harmonisation of economic policies. However, self-employment rates are also influenced by the structure of national economies and the characteristics of national populations. The self-employment rate in a country will be influenced by the structure of industry - some sectors such as agriculture and tourism display higher levels of selfemployment than others. Differences in employment protection legislation regimes across Europe might therefore lead to different self-employment rates. Other reasons to expect differences in self-employment rates relate to individual characteristics. A number of drivers of self-employment are individual-specific and hence less likely to be influenced by national or European policy. For example, personality characteristics, education level, prior experience (both own and parental) and access to capital have all been found to be related to entry to self-employment (see e.g. Simoes, Crespo and Moreira, 2016, for a review). Whilst these factors appear to have consistent effects across European countries, consistent differences between countries are also found (e.g. Taylor, 2011).

Hence there are two competing sets of influences on self-employment rates: convergence caused by closer integration of European economies and resistance caused by national differences in economic and institutional structures and in individual characteristics. Although not the main focus of the study, Taylor (2011) finds little evidence of convergence in self-employment rates in Europe over the period 1993-2007, but does find similarities in the factors associated with self-employment. The aim of this paper is to re-explore the issue and formally test the extent of convergence at the European level and within regions of Europe.

In this paper, we base our approach on previous literature (Durlauf, 2000; Bernard and Durlauf 1994 and 1995; Barro and Sala-i Martin, 2004) and use panel integration and cointegration techniques to test whether or not there is a process of convergence in selfemployment rates within a set of Western, Central, Northern and Southern European counties, and also in Europe as a whole. This approach allows us to distinguish between absolute and conditional convergence. Specifically, an absolute convergence implies that counties with lowest rates of self-employment see those rates grow faster than countries with 
higher rates of self-employment to eventually reach the same long-run equilibrium. In contrast, conditional convergence implies that although growth rates of self-employment converge, cross-economy differences in the level of self-employment do not disappear. Such a result could occur due to structural conditions or the specific employment and labor market policies of each European country. Absolute convergence is less likely to be observed compared to conditional convergence, as it would imply rapid growth in self-employment in countries with lower self-employment rates (although it might be more likely to be seen within groups of countries forming convergence clubs). Conditional convergence on the other hand (converging growth rates) is more likely to arise from economies moving in step through the business cycle (which in turn is influenced by closer economic integration) and is the form of convergence which is more likely to be observed.

The paper is organised as follows. Section 2 describes the data used in this paper; Section 3 discusses the statistical framework; Section 4 presents the results whilst the final section concludes the paper.

\section{Data sources}

We use annual data from 21 European OECD countries over the period 1990-2011. We limit the analysis to this period as it is the window covered by the COMPENDIA database. The advantage of using this data set is that it harmonizes business ownership rates across countries and provides international comparable data on entrepreneurship. ${ }^{1}$ This overcomes problems associated with OECD data that can be subject to differences in operational definitions and survey designs (see Parker et al., 2012; van Stel, 2005). The countries included in our analysis represent four regional groups: (1) Western European countries (Belgium, France, Ireland, The Netherlands and United Kingdom); Central European counties (Austria, Czech Republic, Germany, Hungary, Poland, Slovak Republic and Switzerland); (3) Northern European countries (Denmark, Finland, Iceland, Norway and Sweden); and 4) Southern European counties (Greece, Italy, Portugal and Spain). ${ }^{2}$

Table 1 provides summary statistics of the business ownership (as a percentage of the labour force) for these countries.

[Table 1 about here]

\footnotetext{
${ }^{1}$ In this paper business ownership rate and self-employment rate are used interchangeably.

${ }^{2}$ We base our classification on that in the CIA World Factbook (but we acknowledge that there are other, overlapping, classifications).
} 
Table 1 shows that Greece, Ireland, Italy, Poland, Portugal and Spain have average self-employment rates above the European average. Moreover, Denmark, Germany, Norway, Slovak Republic, Sweden and Switzerland have average self-employment rates below 0.1 and the lowest rates for the whole group over the study period. Generally, Southern European countries have the highest self-employment rates and Northern European counties the lowest ones. $^{3}$

\section{Econometric framework}

To examine convergence of self-employment rates in Europe, we use the following model:

$$
l s e_{i t}=\alpha_{i}+\beta l \widehat{s e}_{t}+\varepsilon_{i t}
$$

where $l s e_{i t}$ is the natural logarithm of self-employment rate for country $i$ at time $t, l \widehat{s e}_{t}=$ $\ln \left(1 / N \sum_{i=1}^{N} s e_{i t}\right)$ is the natural logarithm of the average of the self-employment among the $i$ countries, $\alpha_{i}$ is a constant that denotes permanent differences between each country and the average of the group of countries (Cermeño and Llamosas, 2007). The differences between countries will tend to decline over time and if $\alpha_{i}=0$, it suggests that the differences have been eliminated. Therefore, absolute convergence requires that $\alpha_{i}=0$ and $\beta=1$. In contrast, if $\beta=1$ and $\alpha_{i} \neq 0$ there is evidence of conditional convergence.

A simple way of testing for absolute convergence, is by obtaining the difference between the natural logarithm of the self-employment rate by country and its average, and performing a unit root test to show that it is $I(O)$. This is known as a restricted version of the test and can be written as:

$$
l s e_{i t}-l \widehat{s e}_{t}=\varepsilon_{i t}
$$

The null hypothesis of non-convergence is $H_{0}: l s e_{i t}-l \widehat{s e}_{t}=I(1), \forall i=1, \ldots N$ while the null hypothesis of conditional non-convergence of the non-restricted version can be written as $H_{0}: l s e_{i t}-\alpha_{i}-\beta \widehat{l s e}_{t}=I(1), \forall i=1, \ldots N$. In this paper, we use the test proposed by Maddala and $\mathrm{Wu}(1999)$ that allows the individual autoregressive roots to differ across the cross-sectional units. However, since this test ignores cross-section dependence in the data

\footnotetext{
${ }^{3}$ Since 1999 there has been a steady decline in average employment rates in Southern Europe and more recently an exchange of positions between Central and Western countries. Northern Europe has remained relatively stable since 1990.
} 
we also provide the Pesaran (2007) CIPS test, which allows the individual autoregressive roots to differ across the cross-sectional units and assumes cross-section dependence is in form of a single unobserved common factor.

An alternative way to test for absolute and conditional convergence is to test for cointegration between $l s e_{i t}$ and $l \widehat{s e}_{t}$. Therefore, we apply the seven different cointegration statistics for panel data proposed by Pedroni $(1999,2004)$ which are analogous to the time series statistics discussed by Phillips and Perron (1998) and Phillips and Ouliaris (1990). We apply the Pedroni tests allowing common coefficients for the panel (absolute convergence) and individual coefficients for each cross-section (conditional convergence) and estimate models with a constant and with a constant and a trend. ${ }^{4}$

\section{Empirical results}

We first examine whether or not self-employment (lse) with respect to the mean $l \widehat{s e}_{t}$ $\left(l s e_{i t}-l \widehat{s e}_{t}\right)$ is $I(0)$. The results of the unit root tests are presented in Table 2. The results show that there is no evidence of convergence in European self-employment rates over time as we are unable to reject the null hypotheses of a unit root; convergence would imply that $\left(l s e_{i t}-l \widehat{s e}_{t}\right)$ is $I(0)$. Similar conclusions are drawn for Northern Europe and Central Europe. In the case of the Western Europe, only the Maddala and Wu (1999) unit root test shows evidence of conditional convergence of self-employment rates (at the $10 \%$ level). However, when considering cross-section dependence using the Pesaran (2007) CIPS test, this finding ceases to hold. Finally, for Southern Europe, the unit root tests indicate conditional convergence of self-employment rates with a significant result (again at the 10\% level) for the Maddala and Wu (1999) test and for the Pesaran (2007) test.

\section{[Table 2 about here]}

We then turn to panel cointegration results. Findings from the Pedroni cointegration tests with an intercept and trend included are presented in Table 3 and Table 4 shows results for tests with an intercept and without a trend. Looking at the results among all European countries taken together, Table 3 indicates that there is no evidence of absolute or conditional convergence; none of the test results suggest that the null hypothesis can be rejected.

\footnotetext{
${ }^{4}$ We use the most general specification, with constant and trend, to eliminate possible biases in unit root and cointegration tests (Nelson and Plosser, 1982). We also use the method suggested by Westerlund (2007) and Persyn and Westerlund (2008) and consider four tests assuming that the long-term relationship is heterogeneous with cross-section dependence.
} 
Nevertheless, when no deterministic trend is included in the test for Europe as a whole, some evidence of convergence is found. Specifically, Table 4 shows that two out of four statistics (panel v-statistic and panel PP-statistic) related to within-dimension provide evidence of absolute convergence and one of the three statistics that pool along the between-dimension by taking the average of the coefficients suggests conditional convergence. ${ }^{5}$

\section{[Tables 3-4 about here]}

To obtain a clearer picture, we also examine convergence between countries within each regional group. In the case of the Western European countries, the absolute convergence hypothesis is supported by one test result only when intercept and trend is considered (Table 3); but the remaining results presented in Tables 3 and 4 show no evidence of convergence. ${ }^{6}$ For Central Europe, the absolute convergence hypothesis is supported only in two of the Pedroni cointegration tests, which include the intercept and the trend (Table 3). ${ }^{7}$ For Northern Europe, no absolute or conditional convergence process is observed using the Pedroni cointegration tests (Table 3 and Table 4). ${ }^{8}$ Finally, for Southern Europe, the absolute convergence hypothesis is supported when considering the Pedroni test with intercept and without trend (Table 4). ${ }^{9}$

\section{Conclusions}

This paper examines whether there is a convergence in self-employment rates among 21 OECD European countries. The results provide some weak evidence of convergence across European countries collectively. However, we do find stronger evidence of conditional, but not absolute, convergence in self-employment rates in Northern and Southern Europe, with rather more mixed evidence for Western Europe.

The evidence regarding Central European countries is much more mixed. This may be due to differences in self-employment trends within that region. The decrease in selfemployment rate in Poland and the substantial increase in self-employment rates in both

\footnotetext{
${ }^{5}$ The Westerlund panel cointegration test, however, provides no evidence of conditional convergence.

${ }^{6}$ The results of Westerlund panel cointegration tests show some evidence of conditional convergence.

7 Similarly, using the Westerlund panel cointegration test we find that conditional convergence exists if the constant and trend is included in the test.

${ }^{8}$ But when we consider the Westerlund panel cointegration test without constant and without trend, we find that there is conditional convergence with contemporary dependence, but this is only supported at $90 \%$ confidence level.

${ }^{9}$ In contrast, the four Westerlund panel cointegration tests show evidence of conditional convergence.
} 
Czech Republic and Slovak Republic have contributed to narrowing the gap between them. But this is not observed for Austria, Germany, Hungary and Switzerland. In other words, some countries in that region appear to demonstrate convergence, but not all.

In contrast, in the group of the Southern European countries, we find that selfemployment rates between Italy and Portugal are moving closer to each other, and with the declining trends in both Greece and Spain, the evidence of conditional convergence becomes apparent. Turning to Northern European countries, we find that self-employment rates in Finland, Sweden and Norway are very close to both the group average and to each other. Additionally, Iceland tends to move towards the group average whilst Denmark follows a similar pattern with the group average, but keeping a distance from it. The results also suggest conditional convergence between countries of Northern European. Finally, within Western European countries, Ireland is the one that reduces the self-employment rates to the greatest extent followed by France. The difference between their self-employment rates and the group average is much greater at the end of the period. While for Belgium, United Kingdom and Netherlands there is no clear trend with respect to the average of the group.

Overall, our results would seem to suggest that within the single European labour market, structural differences in self-employment between economies remain. Furthermore, these differences appear to be regionally specific. This would explain the evidence of conditional convergence found within regions and the weaker evidence for convergence across Europe. These findings echo those for economic growth in Europe reported by Monfort et al. (2013), which showed no convergence at the European level, but do show convergence within subsets of European countries (specifically East and West and Core and Periphery). Caminada et al. (2010) found mixed evidence for convergence in terms of social protection and welfare indicators, even finding some evidence of divergence in the case of net total social expenditure. Hence it would seem that the pressure for such variables to converge arising from economic integration and the operation of a single market are countered by national or regional pressures. That self-employment rates display some conditional convergence within regions (that is converge in terms of rate of change but not level) has implications for growth policy. Encouraging entrepreneurship is seen as a way of encouraging economic growth, especially in low growth areas. However, for such entrepreneurship-lead growth to occur, the number of entrepreneurs (proxied here by the number of self-employed) would have to grow. However, the evidence we have of conditional convergence suggests that such growth is unlikely to be faster than that achieved by other countries in the same region of Europe. 
We conclude the paper by identifying some limitations and offering future avenues for research. Our study is based on a proxy for self-employment, but one which is harmonised across countries and avoids potential issues of comparability of definition across countries. However, it remains a proxy for self-employment. The second potential limitation is that self-employment patterns may converge to greater or lesser extents within regions opposing trends may also be seen. A final potential limitation of our study is that we undertake analysis on pre-defined regions (Southern, Western, Northern and Central Europe) which imposes an assumption that self-employment rates will converge only within those groups. One potentially fruitful avenue for future research would be to allow groups of countries with similar self-employment trends to emerge from the data, for example using clustering or finite mixture modelling techniques. Finally, the effect of the financial crisis on the extent of convergence (or divergence) in self-employment would seem to be a fruitful avenue for future research.

\section{Acknowledgements}

We are grateful to four JCMS reviewers for their constructive comments and suggestions. 


\section{References}

Acs, Z. J. (2006) 'How is entrepreneurship good for economic growth?', Innovations, 1(1), 97-107.

Altavilla, C. (2004) 'Do EMU members share the same business cycle?' Journal of Common Market Studies, 42(5), 869-896

Apergis, N. and Georgellis, Y. (2015) 'Does happiness converge?', Journal of Happiness Studies, 16(1), 67-76

Barro, R. and X. Sala-I-Martin (1991) 'Economic Growth in a Cross Section of Countries', Quarterly Journal of Economics, 106, 407-473.

Barro, R. and X. Sala-I-Martin (1992) 'Convergence', Journal of Political Economy, 100, 223-251.

Barro, R., X. and Sala-i Martin (2004) 'Economic Growth', second edition. The MIT Press, Cambridge, MA.

Bendick, M. and M.L. Egan (1987) 'Transfer payment diversion for small business development: British and French experience', Industrial and Labor Relations Review, 40, 528-542.

Bernard, A. B. and S. N. Durlauf (1994) 'Interpreting Test of the Convergence Hypothesis', Technical Working Paper No. 159, National Bureau of Economic Research (NBER).

Bernard, A. B. and S. N. Durlauf (1995) 'Convergence in International Output', Journal of Applied Econometrics, 10(2), 97-108.

Blanchflower, D. (2000) 'Self-employment in OECD countries', Labour Economics, 7, 471505

Blanchflower, D. (2004) 'Self-employment: More may not be better', Swedish Review of Economic Policy, 11(2), 15-72

Caminada, K. Goudswaard, K., and Van Vliet, O. (2010) 'Patterns of welfare state indicators in the EU: Is there convergence?', Journal of Common Market Studies, 48(3), 529556.

Cancelo, J.R. (2012) 'Cyclical synchronisation in the EMU along the financial crisis: An interpretation of conflicting signals', European Journal of Government and Economics, 1(1), 86-100

Cermeño and Llamosas (2007) 'Convergencia del PIB per cápita de 6 países emergentes con Estados Unidos: un análisis de cointegración', EconoQuantum, 4(1), 59-84.

Díaz-Pedroza, J. A. Sánchez-Vargas and M. A. Mendoza-González (2009) 'Convergencia hacia la economía regional líder en México. Un análisis de cointegración en panel', El Trimestre Económico, LXXVI (2), 407-431.

Durlauf, S. (2000) 'Econometric Analysis and the Study of Economic Growth: a Skeptical Perspective', In: Backhouse, R., Salanti, A. (Eds.), Macroeconomics and the Real World. Oxford University Press, Oxford.

European Commission (no date) 'Supporting entrepreneurs and the self-employed', available at: http://ec.europa.eu/social/main.jsp?catId=952\&langId=en (accessed 4/1/18).

European Employment Observatory Review (EEOR) (2010) 'Self-employment in Europe', Report, European Union.

Giannias, D., Liargovas, P. and Manolas, G. (1999) 'Quality of life indices for analysing convergence in the European Union', Regional Studies, 33(1), 27-35.

Hatfield, I. (2015) 'Self-employment in Europe, Report', Institute for Public Policy Research (IPPR).

Koellinger, P. and Thurik, R. (2012) 'Entrepreneurship and the business cycle', Review of Economics and Statistics, 94(4), 1143-1156.

Maddala, G. S., and Wu, S. (1999) 'A Comparative Study of Unit Root Tests with Panel data and New Simple Test’, Oxford Bulletin of Economics and Statistics, 61, 631-652. 
Minniti, M. and Lévesque, M. (2010) 'Entrepreneurial types and economic growth', Journal of Business Venturing, 25(3), 305-314.

Monfort, M., Cuestas, J.C. and Ordóñez, J. (2013) 'Real convergence in Europe: a cluster analysis', Economic Modelling, 33, 689-694.

Nelson, C.R. and Plosser, C.I. (1982) 'Trends and random walks in macroeconomic time series: some evidence and implications', Journal of Monetary Economics, 10, 139162.

Papadimitriou, T., Gogas, P. and Sarantitis, G.A. (2016) 'Convergence of European Business Cycles: A Complex Networks Approach', Computational Economics, 47, 97-119.

Peric, M. and Vitezic, V. (2016) 'Impact of global economic crisis on firm growth', Small Business Economics, 46(1), 1-12.

Parker, S. C. and Robson, M. T. (2004) 'Explaining International Variations in SelfEmployment: Evidence from a Panel of OECD Countries', Southern Economic Journal, 71(2), 287-301.

Parker, S.C. (2004) 'The economics of self-employment and entrepreneurship', Cambridge University Press: Cambridge.

Pedroni, P. (1999) 'Critical Values for Cointegration Tests in Heterogeneous Panels with Multiple Regressors', Oxford Bulletin of Economics and Statistics, Vol. 61, No. 4, pp. 653-670.

Pedroni, P. (2004) 'Panel Cointegration: Asymptotic And Finite Sample Properties Of Pooled Time Series Tests With An Application To The PPP Hypothesis', Econometric Theory. 20(3), 597-625.

Persyn, D. and Westerlund, J. (2008) 'Error correction based cointegration tests for panel data', The STATA journal, 8 (2), 232 - 241.

Pesaran, M. (2007) 'A simple panel unit root test in the presence of cross-section dependence', Journal of Applied Econometrics, vol. 22, issue 2, pp. 265-312.

Phillips, P.C.B. and Ouliaris, S. (1990) 'Asymptotic properties of residual based tests for cointegration', Econometrica, 58, 165-193.

Phillips, P.C.B. and Perron, P. (1998) 'Testing for a unit root in time series regressions', Biometrika, 75, 335-346.

Schindele, Y. (2010) 'How long does it take to become an entrepreneurial society: The case of German convergence in self-employment', Jena economic research papers, No. 2010,015 .

Simoes, N., Crespo, N. and Moreira, S.B. (2016) 'Individual determinants of selfemployment entry: what do we really know?', Journal of Economic Surveys, 30(4), 783-806.

Storey, D. J. (1994) 'Understanding the small business sector', Routledge, London.

Taylor, M. (2011). Self-employment flows and persistence: A European comparative analysis. ISER Working Paper Series No 2011-26.

Torrini, R. (2005) 'Cross-country differences in self-employment rates: the role of institutions', Labour Economics, 12(5), 661-683.

van Stel, A., Carree, M. and Thurik, R. (2005) 'The Effect of Entrepreneurial Activity on National Economic Growth', Small Business Economics, 24(3), 311-321.

Westerlund, J. (2007) 'Testing for error correction in panel data', Oxford Bulletin of Economics ans Statistics, 69, 709 - 748.

Wright, M. and Stigliani, I. (2012) 'Entrepreneurship and Growth', International Small Business Journal, 31(1), 3-22. 
Table 1. European self-employment rates - Summary statistics, 1990-2011

\begin{tabular}{|c|c|c|c|c|c|c|}
\hline Country & Mean & SD & MIN & MEDIAN & MAX & Growth 1990-2011 \\
\hline Austria & 0.117 & 0.004 & 0.108 & 0.117 & 0.123 & 0.22 \\
\hline Belgium & 0.126 & 0.004 & 0.119 & 0.125 & 0.131 & -0.23 \\
\hline Czech Republic & 0.135 & 0.028 & 0.080 & 0.142 & 0.175 & 5.94 \\
\hline Denmark & 0.079 & 0.003 & 0.075 & 0.079 & 0.088 & -0.57 \\
\hline Finland & 0.118 & 0.007 & 0.110 & 0.118 & 0.137 & -0.69 \\
\hline France & 0.103 & 0.010 & 0.093 & 0.099 & 0.127 & -0.94 \\
\hline Germany & 0.095 & 0.008 & 0.081 & 0.094 & 0.108 & 1.43 \\
\hline Greece & 0.289 & 0.021 & 0.257 & 0.283 & 0.325 & -1.02 \\
\hline Hungary & 0.126 & 0.013 & 0.104 & 0.128 & 0.144 & -0.87 \\
\hline Iceland & 0.139 & 0.012 & 0.115 & 0.141 & 0.156 & -0.80 \\
\hline Ireland & 0.171 & 0.021 & 0.137 & 0.166 & 0.208 & -1.71 \\
\hline Italy & 0.228 & 0.007 & 0.212 & 0.230 & 0.236 & -0.49 \\
\hline Norway & 0.097 & 0.008 & 0.085 & 0.097 & 0.110 & -0.91 \\
\hline Poland & 0.188 & 0.016 & 0.168 & 0.186 & 0.212 & -0.63 \\
\hline Portugal & 0.231 & 0.019 & 0.184 & 0.236 & 0.259 & -0.82 \\
\hline Slovak Republic & 0.081 & 0.032 & 0.047 & 0.065 & 0.137 & 9.57 \\
\hline Spain & 0.153 & 0.012 & 0.124 & 0.155 & 0.168 & -1.31 \\
\hline Sweden & 0.095 & 0.004 & 0.086 & 0.096 & 0.102 & 0.63 \\
\hline Switzerland & 0.094 & 0.008 & 0.082 & 0.091 & 0.110 & -0.38 \\
\hline The Netherlands & 0.121 & 0.008 & 0.105 & 0.121 & 0.133 & 1.33 \\
\hline United Kingdom & 0.118 & 0.005 & 0.109 & 0.119 & 0.125 & -0.04 \\
\hline Total Europe & 0.138 & 0.003 & 0.133 & 0.138 & 0.143 & \\
\hline Western Europe & 0.128 & 0.005 & 0.121 & 0.125 & 0.138 & \\
\hline Central Europe & 0.119 & 0.006 & 0.106 & 0.120 & 0.129 & \\
\hline Northern Europe & 0.106 & 0.004 & 0.100 & 0.106 & 0.112 & \\
\hline Southern Europe & 0.225 & 0.013 & 0.194 & 0.227 & 0.242 & \\
\hline
\end{tabular}


Table 2. Unit root tests

\begin{tabular}{|c|c|c|c|c|c|c|}
\hline \multirow{2}{*}{$\begin{array}{l}\text { Unit Root Test } \\
\text { Null: Unit root (assumes individual unit } \\
\text { root process) }\end{array}$} & \multicolumn{2}{|c|}{ Total Europe } & \multicolumn{2}{|c|}{ Western Europe } & \multicolumn{2}{|c|}{ Central Europe } \\
\hline & Statistic & Prob. & Statistic & Prob. & Statistic & Prob. \\
\hline \multicolumn{7}{|l|}{ Maddala and Wu (1999) test (MW) } \\
\hline Chi-square without trend & 22.15 & 1.00 & 17.94 & 0.06 & 4.67 & 0.99 \\
\hline Chi-square with trend & 28.65 & 0.94 & 6.01 & 0.82 & 7.09 & 0.93 \\
\hline \multicolumn{7}{|l|}{ Pesaran (2007) test (CIPS) } \\
\hline Zt-bar without trend & 0.68 & 0.75 & -0.96 & 0.17 & 1.22 & 0.89 \\
\hline Zt-bar with trend & 3.08 & 1.00 & 0.60 & 0.73 & 2.46 & 0.99 \\
\hline \multicolumn{3}{|l|}{ Unit Root Test } & \multicolumn{2}{|c|}{ Northern Europe } & \multicolumn{2}{|c|}{ Southern Europe } \\
\hline $\begin{array}{l}\text { Null: Unit root (assumes individual unit } \\
\text { root process) }\end{array}$ & & & Statistic & Prob. & Statistic & Prob. \\
\hline \multicolumn{7}{|l|}{ Maddala and Wu (1999) test (MW) } \\
\hline Chi-square without trend & & & 7.50 & 0.68 & 5.80 & 0.67 \\
\hline Chi-square with trend & & & 9.29 & 0.51 & 13.99 & 0.08 \\
\hline \multicolumn{7}{|l|}{ Pesaran (2007) test (CIPS) } \\
\hline Zt-bar without trend & & & -0.64 & 0.26 & -2.17 & 0.02 \\
\hline Zt-bar with trend & & & 2.07 & 0.98 & -0.99 & 0.16 \\
\hline
\end{tabular}


Table 3. Pedroni's panel cointegration test with intercept and trend.

\begin{tabular}{|c|c|c|c|c|c|c|}
\hline \multirow{2}{*}{$\begin{array}{l}\text { Null Hypothesis: No cointegration } \\
\text { Alternative hypothesis: common AR } \\
\text { coefficients }\end{array}$} & \multicolumn{2}{|c|}{ Total Europe } & \multicolumn{2}{|c|}{ Western Europe } & \multicolumn{2}{|c|}{ Central Europe } \\
\hline & & Weighted & & Weighted & & Weighted \\
\hline & Prob. & Prob. & Prob. & Prob. & Prob. & Prob. \\
\hline Panel $v$-Statistic & 0.27 & 0.62 & 0.04 & 0.07 & 0.00 & 0.08 \\
\hline Panel rho-Statistic & 1.00 & 0.99 & 0.76 & 0.62 & 0.68 & 0.40 \\
\hline Panel PP-Statistic & 0.98 & 0.76 & 0.52 & 0.28 & 0.43 & 0.09 \\
\hline Panel ADF-Statistic & 1.00 & 1.00 & 0.25 & 0.34 & 0.96 & 0.94 \\
\hline \multicolumn{7}{|l|}{$\begin{array}{l}\text { Alternative hypothesis: individual AR } \\
\text { coefficients }\end{array}$} \\
\hline & Prob. & & Prob. & & Prob. & \\
\hline Group $\rho$-Statistic & 1.00 & & 0.84 & & 0.84 & \\
\hline Group $t$-Statistic (non-parametric) & 0.77 & & 0.39 & & 0.36 & \\
\hline Group $t$-Statistic (parametric) & 1.00 & & 0.22 & & 0.99 & \\
\hline Null Hypothesis: No cointegration & & & \multicolumn{2}{|c|}{ Northern Europe } & \multicolumn{2}{|c|}{ Southern Europe } \\
\hline \multicolumn{3}{|l|}{$\begin{array}{l}\text { Alternative hypothesis: common } A R \\
\text { coefficients }\end{array}$} & & Weighted & & Weighted \\
\hline & & & Prob. & Prob. & Prob. & Prob. \\
\hline Panel v-Statistic & & & 0.95 & 0.93 & 0.21 & 0.51 \\
\hline Panel rho-Statistic & & & 0.87 & 0.81 & 0.45 & 0.38 \\
\hline Panel PP-Statistic & & & 0.61 & 0.42 & 0.19 & 0.16 \\
\hline Panel ADF-Statistic & & & 0.98 & 0.98 & 0.10 & 0.29 \\
\hline \multicolumn{7}{|l|}{$\begin{array}{l}\text { Alternative hypothesis: individual AR } \\
\text { coefficients }\end{array}$} \\
\hline \multicolumn{7}{|l|}{ (between dimension) } \\
\hline & & & Prob. & & Prob. & \\
\hline Group $\rho$-Statistic & & & 0.94 & & 0.75 & \\
\hline Group $t$-Statistic (non-parametric) & & & 0.56 & & 0.38 & \\
\hline Group $t$-Statistic (parametric) & & & 1.00 & & 0.42 & \\
\hline
\end{tabular}

Notes: Automatic lag length selection based on AIC with lags from 2 to 4; Newey-West automatic bandwidth selection and Bartlett kernel. 
Table 4. Pedroni's panel cointegration test with intercept and without trend.

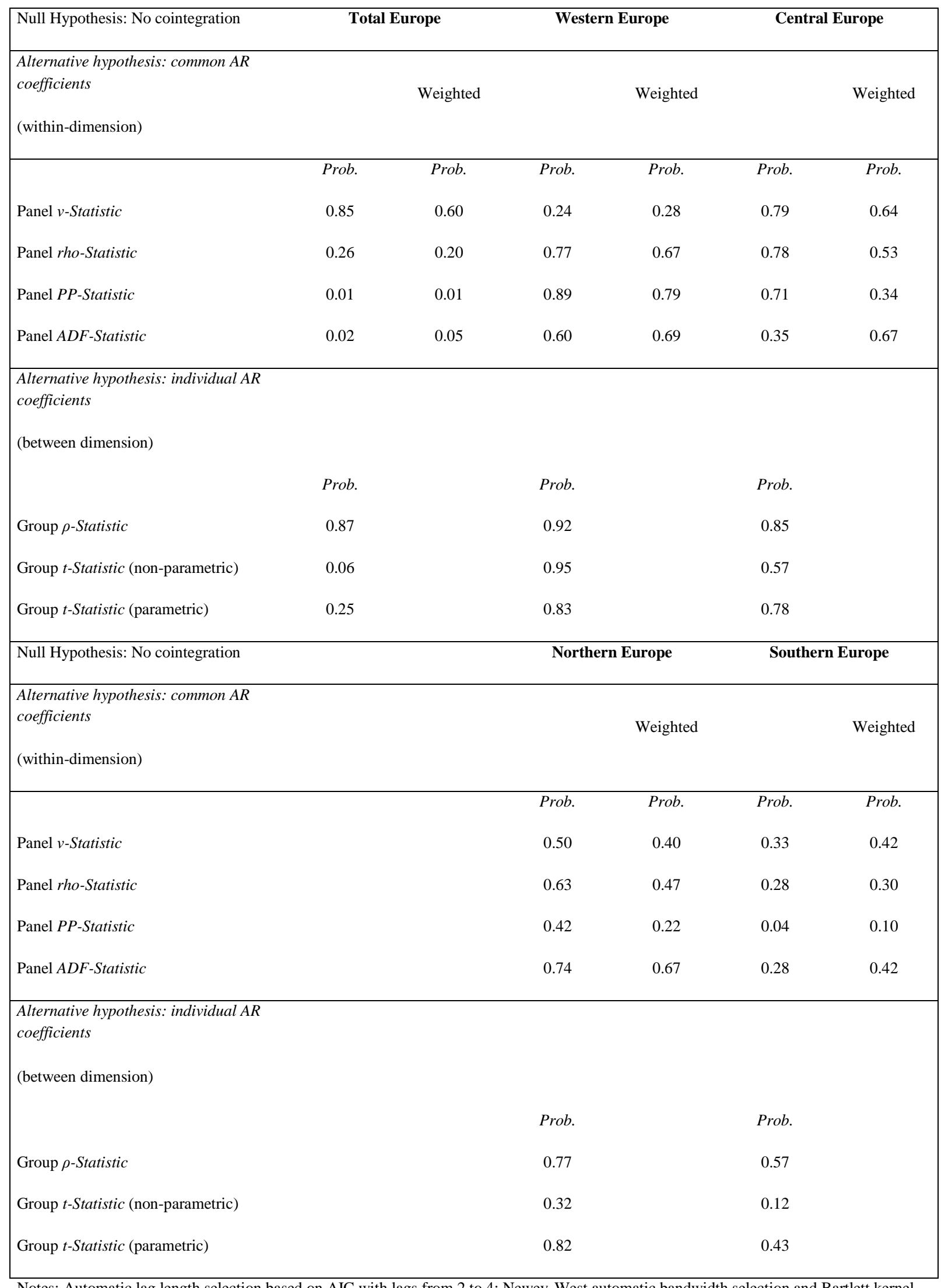

Notes: Automatic lag length selection based on AIC with lags from 2 to 4; Newey-West automatic bandwidth selection and Bartlett kernel. 